\title{
CRIME OF AGGRESSION: EXPANDING THE RELATIVELY NARROW PARAMETERS OF ARTICLE 8 BIS OF THE ROME STATUTE
}

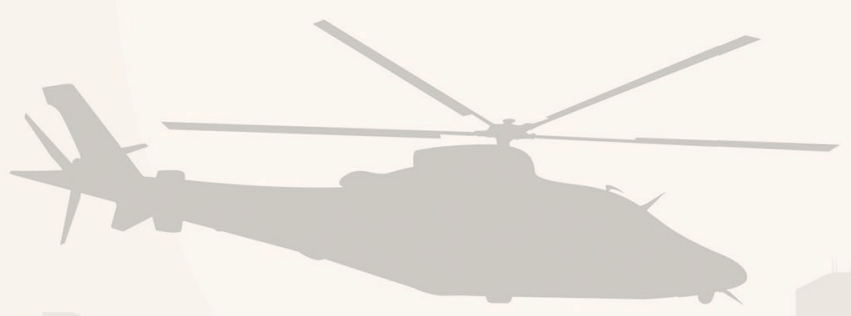

Karan Godara
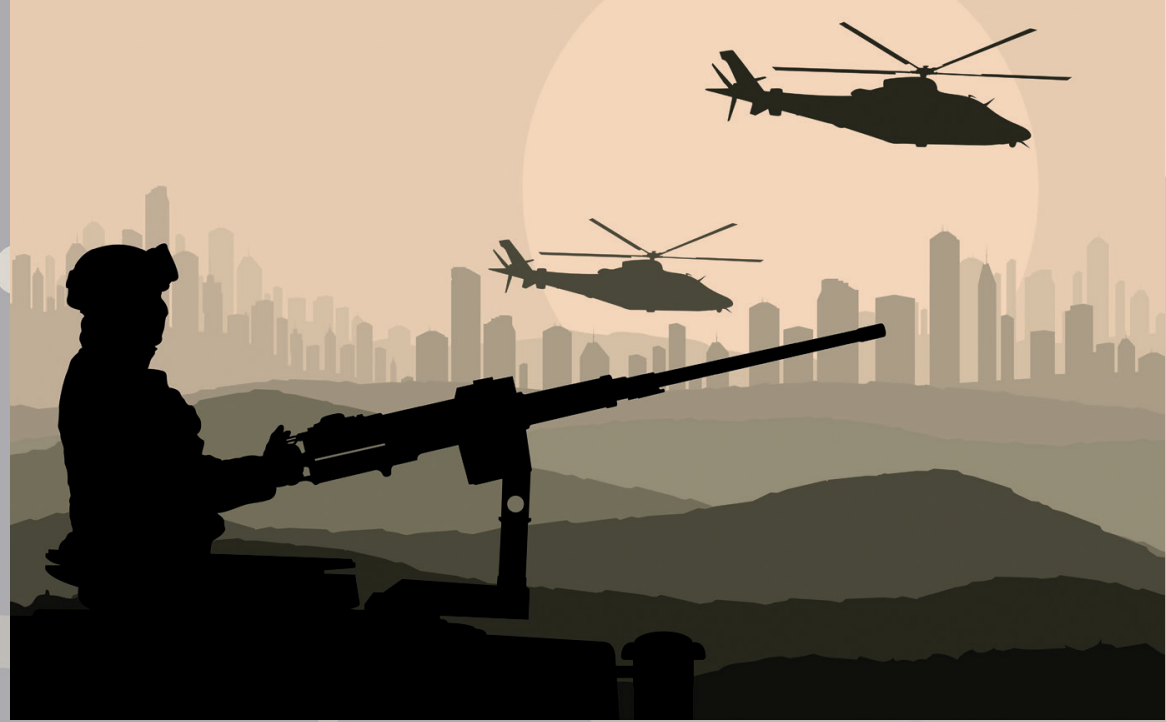



\title{
CRIME OF AGGRESSION: EXPANDING THE RELATIVELY NARROW PARAMETERS OF ARTICLE 8 BIS OF THE ROME STATUTE
}

\author{
KARAN GODARA
}

Panjab University

\begin{abstract}
The criminalization of aggression, which is diametrically opposed to the notion of state sovereignty, has remained in a state of suspended animation until recently. Effective starting on July 17, 2018, the International Criminal Court has been empowered to try individuals for the crime of aggression. Although achieving this feat is commendable in itself, there is no denying the fact that the definition adopted under Article 8 bis of the Rome Statute is outmoded. Being a synthesis between the provisions of two outworn documents of the $20^{\text {th }}$ century, namely the Nuremberg Charter (1945), on the one hand, and the United Nations General Assembly Resolution 3314 (XXIX) (1974), on the other, Article 8 bis seems ill-equipped for the purpose of handling new-age challenges brewing in the $21^{\text {st }}$ century. The author has attempted to summarize the evolution of the crime of aggression as a prelude to presenting a case for the need to adopt a far more inclusive definition within the scheme of Article 8 bis, i.e. taking into consideration the exigencies of the $21^{\text {st }}$ century emanating from (a) non-traditional means of warfare, such as cyberwarfare; (b) non-state entities, such as terrorist groups; and (c) internal acts of aggression.
\end{abstract}

Keywords: Rome Statute, International Criminal Court (ICC), crime of aggression, Kampala Review Conference.

About the author: Research Scholar at the Department of Laws, Panjab University. Recipient of the 'Legislative Assistants to Members of Parliament' Fellowship 2011-2012. India

Received: October 21, 2018; reviewed: December 10, 2018; accepted: March 12, 2019 


\title{
EL CRIMEN DE AGRESIÓN: AMPLIAR LOS PARÁMETROS RELATIVAMENTE ESTRECHOS DEL ARTÍCULO 8 BIS DEL ESTATUTO DE ROMA
}

\author{
Karan Godara
}

PANJAB University

\section{Resumen}

La criminalización de la agresión, diametralmente opuesta a la noción de la soberanía del Estado, se mantuvo en un estado de animación suspendida hasta hace poco. A partir del 17 de julio de 2018, la Corte Penal Internacional ha sido facultada para juzgar a individuos por el crimen de agresión. Aunque el logro de esta hazaña es admirable en sí mismo, no se puede negar el hecho de que la definición adoptada en el Artículo 8 bis del Estatuto de Roma está anticuada. Siendo una síntesis de las disposiciones de dos documentos obsoletos del siglo XX, a saber, la Carta de Nuremberg (1945), por un lado, y la Resolución 3314 (XXIX) de la Asamblea General de las Naciones Unidas (1974), por el otro, el Artículo 8 bis parece mal equipado para el propósito de manejar los desafíos de la nueva era que se están gestando en el siglo XXI. El autor buscó resumir la evolución del crimen de agresión como preludio para presentar el caso de que es necesario adoptar una definición mucho más incluyente dentro del esquema del Artículo 8 bis; es decir, es indispensable tener en cuenta las exigencias del siglo XXI que emanan de (a) medios de guerra no tradicionales, como la guerra cibernética; (b) entidades no estatales, como los grupos terroristas; y (c) actos internos de agresión.

Palabras clave: Estatuto de Roma, Corte Penal Internacional (CPI), crimen de agresión, Conferencia de Revisión de Kampala.

El Autor: Investigador en el Departamento de Derecho de la Universidad de Panjab. Destinatario de la beca "Asistentes legislativos para miembros del parlamento" (2011-2012).

Recibido: 21 de octubre de 2018; evaluado: 10 de diciembre de 2018; aceptado: 12 de marzo de 2019. 


\section{Introduction}

"Ever since the judgment at Nuremberg, it has been undeniable that aggressive war is not a national right but an international crime."

Benjamin B. Ferencz, prosecutor at the Nuremberg trials

Given that the criminalization of aggression is diametrically opposed to the notion of state sovereignty, it is no surprise that the crime of aggression has remained in a state of suspended animation until recently. Since countries continue to partake in war-related activities, no consensus could be reached amongst states regarding the intricacies of the crime of aggression during the negotiation sessions for the adoption of the Rome Statute of the International Criminal Court² in 1998.

The Nuremberg Tribunal came down heavily on the "war of aggression," ruling to the effect that initiating a war of aggression is "not only an international crime; it is the supreme international crime" as its consequences are not merely limited to belligerent states, but rather affect the whole world. ${ }^{3}$ Looking back at the history of the supreme international crime, the post-World War II ad hoc tribunals were the first to hand out sentences to individuals for crimes against peace [read as "aggression"]; it took more than half a century before any international tribunal or court could be granted the power to prosecute individuals for the commission of the crime of aggression. The Assembly of State Parties (hereinafter called ASP) in its $16^{\text {th }}$ session, by consensus, adopted a resolution to activate the crime of aggression under the Rome Statute effective starting on July 17, 2018. ${ }^{4}$ Indeed, the inclusion of the crime of aggression within the scheme of the Rome Statute stems from the desire of the international community to see that the supreme international crime attracts individual criminal liability, as it once did under the Nuremberg and Tokyo Charters. $^{5}$

1 Benjamin B. Ferencz, "Address to the Diplomatic Conference of Plenipotentiaries on the Establishment of an International Criminal Court." Rome (June 16, 1998). Available from: http://www.derechos.org/nizkor/ aggression/doc/bferencz6.html

2 Rome Statute of the International Criminal Court (July 17, 1998) (entered into force on July 1 , 2002) [hereinafter called the Rome Statute]. Available from: https://treaties.un.org/pages/ViewDetails. aspx?src=TREATY\&mtdsg_no=XVIII-10\&chapter $=18 \&$ lang=en

3 International Military Tribunal, Trial of the Major War Criminals before the International Military Tribunal, Vol. 1. (Nuremberg, 1947), 186. Available from: https://www.loc.gov/rr/frd/Military_Law/pdf/NT_Vol-I.pdf

4 International Criminal Court, Assembly activates court's jurisdiction over crime of aggression. Press release (Dec. 15, 2017). Available from: https://www.icc-cpi.int/Pages/item.aspx?name=prl350

5 Kriangsak Kittichaisaree, International Criminal Law, 1t ed. (Oxford: Oxford University Press, 2001), 207. 
With the recent activation of the crime of aggression under the Rome Statute, individual accountability for the commission of international crimes has once again been reiterated as a principle of international criminal law. At this juncture, it would be apt to recall the classic pronouncement made by the Nuremberg Tribunal: "Crimes against international law are committed by men, not by abstract entities, and only by punishing individuals who commit such crimes can the provisions of international law be enforced." ${ }^{\prime 6}$

Despite this momentous development in the field of international criminal law, there can be no denial of the fact that the definition adopted under Article 8 bis of the Rome Statute seems ill-equipped for the purpose of handling new-age challenges brewing in the $21^{\text {st }}$ century. Being a synthesis between the provisions of two outworn documents of the $20^{\text {th }}$ century, namely the Nuremberg Charter (1945), on the one hand, and the United Nations General Assembly Resolution 3314 (XXIX) (1974), on the other, Article 8 bis in its current lackluster and archaic form is bound to have negative implications on global peace and security in the times to come. Cyberwarfare and terrorist groups are emerging as new-age challenges, so much so that nation-states are finding it difficult to cope with their mounting pressure. This paper systematically summarizes the evolution of the crime of aggression as a prelude to presenting a case for the strengthening of the definition of aggression, duly examining imminent threats posed to global peace and security. To transcend the impediments presented by the current structure of Article 8 bis, the ensuing parts of the paper expand on the need for amending the definition clause in order to make the definition inclusive of new-age threats that emanate from (a) non-traditional means of warfare, such as cyberwarfare; (b) non-state entities, such as terrorist groups; and (c) internal acts of aggression.

\section{Evolution of the crime of aggression}

When we speak of the crime of aggression, we must scrutinize the concept with caution, bearing in mind the fine distinction between the "act of aggression" and the "crime of aggression." While the former is about state action, the latter seeks to end impunity enjoyed by individuals responsible for the supreme international crime of aggression. To better comprehend the operational bounds of the crime of aggression, it is important to discuss its evolution culminating in the coming into force of Article 8 bis of the Rome Statute.

International Military Tribunal, Trial, 223. 
Although by the turn of the $20^{\text {th }}$ century, efforts to denounce certain war-related injustices had begun to take shape in the form of the Hague Peace Conferences in 1899 and 1907, it was much later in 1928 that the first comprehensive ban on war was adopted via the Kellogg-Briand Pact, which renounced war as an instrument of national policy. ${ }^{7}$ While the pact of 1928 stipulated state responsibility, it did nothing to address the issue of criminalization of individuals for acts of aggression. ${ }^{8}$ Having realized the futility of war in the aftermath of World War II, prohibition on aggression by nation-states was significantly strengthened through the adoption of the UN Charter. Article 39 of the charter empowers the United Nations Security Council to determine if any nation-state has committed an act of aggression. However, since the charter does not authorize the determination of individual criminal liability, the issue of criminalization of individuals for aggression remains unaddressed.

The Nuremberg Charter was the first treaty under international criminal law to establish individual criminal responsibility for waging a war of aggression. Whereas twelve persons were convicted in Nuremberg for crimes against peace, 25 were convicted in Tokyo for the same reason. Additionally, two defendants were convicted in the Nuremberg follow-up trials for the supreme international crime. ${ }^{9}$

The notion of individual criminal liability for acts of aggression was once again left in the lurch after the tenure of the Nuremberg (including the follow-up trials) and the Tokyo tribunals came to an end. More than 70 years later, effective starting on July 17,2018 , this vacuum has been filled by the Rome Statute. Indeed, the journey from Nuremberg to Rome and beyond (as will be demonstrated hereinafter) has been arduous.

When the Rome Statute was adopted in 1998, it specifically laid down under Article 5 that "the jurisdiction of the Court shall be limited to the most serious crimes of concern to the international community as a whole." One such crime enlisted under Article 5 was the crime of aggression. However, since no consensus amongst nation-states could be reached either regarding the definition of aggression or regarding the conditions of the court's jurisdiction, ${ }^{10}$ it was uncertain whether the

Gerhard Werle and Florian Jessberger, Principles of International Criminal Law, $3^{\text {rd }}$ ed. (Oxford: Oxford University Press, 2014), 530-532.

8 Illias Bantekas, International Criminal Law, $4^{\text {th }}$ ed. (Oxford and Portland, Oregon: Hart Publishing, 2010), 288.

9 Werle and Jessberger, Principles, 535.

10 Werle and Jessberger, Principles, 546. 
ICC's jurisdiction in regard to the crime of aggression would ever be activated or not. Benjamin B. Ferencz, summing up the attitude of various states during the final plenipotentiary negotiating sessions held in Rome (1998), noted to the effect that:

a. the majority of nation-states, including the members of the EU and roughly 30 nation-states united in the Non-Aligned Movement, insisted upon the inclusion of the crime of aggression;

b. many of the Arab states were in favour of adopting the 1974 United Nations General Assembly's definition of aggression enumerated under the United Nations General Assembly Resolution 3314 (XXIX) of 14 December 1974; and

c. India, Pakistan, China \& the USA were not inclined to subject themselves to the crime of aggression due to different political considerations.

Finally, due to the paucity of time, the chairman decided to postpone the resolution of the issues connected to aggression to a later date. ${ }^{11}$

To continue deliberations on the issues that were left unresolved at the plenipotentiary negotiating sessions, a Preparatory Commission for the International Criminal Court was brought to life through Resolution F of the final act at the United Nations Diplomatic Conference of Plenipotentiaries (1998). One of its many mandates was to prepare proposals regarding the crime of aggression. ${ }^{12}$ Being unable to fulfill its mandate in regard to the crime of aggression before its tenure expired (2002), a Special Working Group on the Crime of Aggression (hereinafter called SWGCA) was established in 2002 by the ASP to carry forth the commission's work. ${ }^{13}$ The SWGCA was given the onerous task of submitting proposals to the ASP regarding acceptable provisions on the crime of aggression that could be considered at the review conference.

11 Benjamin B. Ferencz, "Can Aggression Be Deterred by Law?" Pace International Law Review 11 (1999), 341, 351.

12 United Nations, Preparatory Commission for the International Criminal Court (1999-2002). Available from: http://legal.un.org/icc/prepcomm/prepfra.htm

13 United Nations, "Draft resolution of the Assembly of States Parties on the continuity of work in respect of the crime of aggression" (2002). Available from:

https://documents-dds-ny.un.org/doc/UNDOC/LTD/N02/472/04/PDF/N0247204.pdf?OpenElement 
The SWGCA's proposals were accepted by the ASP in $2009,{ }^{14}$ and the same came to be approved at the Kampala Review Conference held in 2010, ${ }^{15}$ twelve years after the Rome Statute was originally adopted. The definition adopted at Kampala is as follows:

1. For the purpose of this Statute, "crime of aggression" means the planning, preparation, initiation or execution, by a person in a position effectively to exercise control over or to direct the political or military action of a State, of an act of aggression, which, by its character, gravity, and scale, constitutes a manifest violation of the Charter of the United Nations.

2. For the purpose of paragraph 1 , "act of aggression" means the use of armed force by a State against the sovereignty, territorial integrity or political independence of another State, or in any other manner inconsistent with the Charter of the United Nations. Any of the following acts, regardless of a declaration of war, shall, in accordance with the United Nations General Assembly resolution 3314 (XXIX) of 14 December 1974, qualify as an act of aggression:

a. The invasion or attack by the armed forces of a State of the territory of another State, or any military occupation, however temporary, resulting from such invasion or attack, or any annexation by the use of force of the territory of another State or part thereof;

b. Bombardment by the armed forces of a State against the territory of another State or the use of any weapons by a State against the territory of another State;

c. The blockade of the ports or coasts of a State by the armed forces of another State;

d. An attack by the armed forces of a State on the land, sea or air forces, or marine and air fleets of another State;

4 International Criminal Court, "Resolution ICC-ASP/8/Res.6" (2009). Available from: https://asp.icc-cpi.int/ iccdocs/asp_docs/Resolutions/ICC-ASP-8-Res.6-ENG.pdf

15 United Nations, "Resolution RC/Res.6" (2010). Available from: https:/treaties.un.org/doc/source/docs/ RC-Res.6-ENG.pdf 
e. The use of armed forces of one State, which are within the territory of another State with the agreement of the receiving State, in contravention of the conditions provided for in the agreement or any extension of their presence in such territory beyond the termination of the agreement;

f. The action of a State in allowing its territory, which it has placed at the disposal of another State, to be used by that other State for perpetrating an act of aggression against a third State;

g. The sending by or on behalf of a State of armed bands, groups, irregulars or mercenaries, which carry out acts of armed force against another State of such gravity as to amount to the acts listed above, or its substantial involvement therein.

The aforementioned definition, which came into force on July 17, 2018, is deemed to play a pivotal role in deterring leaders and high ranking officers of nation-states from making territorial transgressions in the times to come and, therefore, is a welcome step.

\section{The ambit of the crime of aggression under Article 8 bis of the Rome Statute}

An analysis of Article 8 bis reveals that it is an amalgamation of Article $6(a)^{16}$ of the Charter of the International Military Tribunal (1945), on the one hand, and the resolution adopted by the United Nations General Assembly (1974), ${ }^{17}$ on the other, albeit with a few modifications.

\subsection{Key concepts with respect to Article 8 bis}

Various aspects relating to the definition clause are discussed below in order to fully comprehend the operational bounds of Article 8 bis of the Rome Statute.

16 Article 6 (a) reads: "Crimes against Peace: namely, planning, preparation, initiation or waging of a war of aggression, or a war in violation of international treaties, agreements or assurances, or participation in a common plan or conspiracy for the accomplishment of any of the foregoing."

17 United Nations General Assembly, "Resolution adopted by the General Assembly 3314 (XXIX). Definition of Aggression" (Dec. 14, 1974). Available from: http://www.un-documents.net/a29r3314.htm 
Aggression. The usage of the term "aggression" under Article 8 bis needs to be scrutinized from two angles, i.e. from the perspective of the individual and that of the state. Whereas the term "crime of aggression" is used in an individual-centric sense, "act of aggression" is state-centric in its nature. Based on these two conceptualizations adopted under Article 8 bis, it can be logically concluded that to attract individual criminal responsibility for the crime of aggression, it must first be established that a state committed an act of aggression. Without establishing an act of aggression on the part of the state, all efforts to prosecute individuals for the connected crime of aggression would be in vain.

Modes of committing the crime of aggression. The four modes to attract individual liability for the crime of aggression under Article 8 bis are "planning, preparation, initiation or execution." Whereas the use of the words "planning," "preparation," and "initiation" have been adopted in letter and spirit from the statute of the Nuremberg Tribunal, ${ }^{18}$ there is a divergence from the erstwhile tribunal in the terminology used for the last mode, i.e. "waging of a war of aggression" has been replaced with the term "execution" under the Rome Statute. It is submitted ${ }^{19}$ that the change in terminology does not effectuate a change in the substance of the conduct required. Actual occurrence of an act of aggression is still a pre-requisite for holding an individual liable for the execution of the crime of aggression.

Leadership crime. It is inferable from the Nuremberg and the Tokyo judgments that only high-ranking political, military or industrial leaders involved at the policymaking level were prosecutable perpetrators of crimes against peace. ${ }^{20}$ In fact, it had been explicitly stated in Article II (2) (f) of the Control Council Law No. $10^{21}$ that for an individual to have committed a crime against peace, it must be established that he held a high political, civil or military (including General Staff) position or a high position in the financial, industrial or economic life. The rationale behind adopting the leadership clause has been succinctly explained in the High Command Trial in this way: "Somewhere between the Dictator and Supreme Commander of the Military Forces of the nation and the common soldier is the boundary between the criminal and the excusable participation in the waging of an aggressive war by an individual engaged in it." 22

\footnotetext{
See Art. 6 (a) of the Statute of the International Military Tribunal (8 Aug. 1945, 82 UNTS 1951), 280.

Kai Ambos, "The crime of aggression after Kampala." German Yearbook of International Law 53 (2010), 463, 468. Werle \& Jessberger, 542.

21 Law No. 10 was enacted in order to establish a uniform legal basis in Germany for the prosecution of war criminals and other similar offenders, other than those dealt with by the International Military Tribunal.

22 The United States of America vs. Wilhelm von Leeb et al. (Nuremberg: US Military Tribunal, 1948).
} 
The liability of high-ranking leaders, on the one hand, and the excusable participation of subordinate officers, on the other, has been rightly retained under the Rome Statute, i.e. only a person who is "in a position effectively to exercise control over or to direct the political or military action of a State"23 can be prosecuted for the crime of aggression. However, there appears to have been a divergence from the post-World War II ad hoc tribunals insofar as it seems to the author that it is not the intent of the Rome Statute that persons holding influential positions other than those relating to the political or military divisions be held liable for the supreme international crime. Had the intention been otherwise, Article 8 bis would have explicitly extended liability to persons holding "high position in the financial, industrial or economic life", ${ }^{24}$ as done under the Control Council Law No. 10.

Threshold clause. Only those acts of aggression will incur liability under Article 8 bis (1) of the Rome Statute that, due to their character, gravity, and scale, constitute a manifest violation of the UN Charter. The limitations attached to what may constitute an act of aggression helps in creating a threshold and affording protection to state leaders and high-ranking officers against the over-criminalization of aggression, i.e. excluding liability for minor incidents, such as border skirmishes, or legally controversial cases, such as humanitarian interventions. ${ }^{25}$

Act of aggression under Article 8 bis (2) (a) to (g) regardless of declaration of war. Provisions incorporated under Article 8 bis (2)(a) to (g) are a verbatim reproduction of Article 3(a) to (g) of the 1974 United Nations General Assembly Resolution. ${ }^{26}$ The purpose of these sub-clauses is to extend the repercussions of an act of aggression to situations where the conduct of a state is such so as to warrant a particular act's classification as an act of aggression, irrespective of whether war stands declared or not. It is appalling that the 1974 antiquated classificatory scheme focusing entirely on state-action has been retained in the $21^{\text {st }}$ century, when war is no longer fought conventionally amongst nation-states, but rather is dominated by non-state actors, such as ISIS, Al-Queda, Boko Haram, etc. The definition relevant only to state-action (including "armed bands, groups, irregulars or mercenaries" acting on behalf of a

\footnotetext{
3 Rome Statute, Art. 8 bis (1).

24 See Article II (2) (f), "Control Council Law No. 10." Control Council for Germany $50-55$ (1945). Available from: https://www.legal-tools.org/doc/ffda62/pdf/

25 Ambos, "The Crime of Aggression," 482-483.

26 United Nations General Assembly, "Resolution."
} 
state $)^{27}$ fails to take into account the pre-dominant threat of the $21^{\text {st }}$ century, i.e. acts of aggression by non-state entities. ${ }^{28}$

\subsection{Shortcomings within the scheme of Article 8 bis}

In its current letter and spirit, the utility of Article 8 bis seems very limited and restrictive. An in-depth analysis of the definition clause reveals several missing pieces to the puzzle, which require the immediate attention of the international community, including the following issues that deserve reconsideration.

A narrow meaning ascribed to "act of aggression." ${ }^{29}$ It has been argued ${ }^{30}$ that the concept of war and peace as adopted under the UN Charter, along with the "underdeveloped notion of the criminality of waging aggressive war, based on the legacy of Nuremberg", ${ }^{31}$ is ill-equipped to deal with the advancement in conventional and non-conventional means of warfare that have taken root in the $21^{\text {st }}$ century, i.e. new-age threats to world peace and security, such as "cyberwar, low intensity asymmetric conflict scenarios, global terrorism, organized crime and piracy." 32

In 2007, Estonia became the world's first country to bear the wrath of cyberwarfare. It is alleged that the cyber-attacks on Estonian banks, media outlets, and governmental bodies was state-sponsored (Russia), carried out as an act of retribution for the removal of a Soviet bronze soldier statute from the Estonian capital Tallinn. ${ }^{33}$

Cyberwarfare was non-existent when the UN General Assembly defined the contours of inter-state aggression in 1974. Today, cyberwarfare has the capacity to overpower nation-states without the aid of physical warfare. Failure to take into account technological advancements that have taken place ever since has immobilized the

The Rome Statute, Art. 8 bis (2)(g).

28 David Scheffer, "The Missing Pieces in Article 8 bis (Aggression) of the Rome Statute,." Harvard International Law Journal 58 (2017), 83-84. Available from: http://www.harvardilj.org/2017/04/ the-missing-pieces-in-article-8-bis-aggression-of-the-rome-statute/

29 The Rome Statute, Art. 8 bis (2).

30 Sascha-Dominik Bachmann and Gerhard Kemp, "Aggression as 'Organized Hypocrisy?' - How the War on Terrorism and Hybrid Threats Challenge the Nuremberg Legacy." The Windsor Yearbook of Access to Justice Vol. 30, No. 1 (2011). Available from: http://dx.doi.org/10.2139/ssrn.1871912

31 Bachmann and Kemp, "Aggression".

32 Bachmann and Kemp, "Aggression".

33 Damien McGuinness, "How a cyber attack transformed Estonia." BBC News (Apr. 27, 2017). Available from: https://www.bbc.com/news/39655415 
ICC and prevented it from investigating new-age situations of aggression consisting "solely or largely of cyberwarfare tactics." ${ }^{34}$

From the foregoing discussion, it is clear that a nation-state's sovereignty can be challenged through the virtual space in this day and age. Therefore, it is the call of the hour that the means of transgressing another country's "sovereignty, territorial integrity or political independence" be not limited merely to the "use of armed force," as currently provided under Article 8 bis (2).

A limiting state-centric approach taken to the commission of acts of aggression. Under the current setup of Article 8 bis, an individual can be prosecuted for the crime of aggression only once it is established that the act of aggression was committed by a nation-state. In accordance with Article 8 bis (1), only persons exercising control or directing the political or military action of a state can be held individually liable. This narrow approach exempts "aggressive warfare waged by non-state entities across national boundaries." 35

Enunciating the customary rules of International Criminal Law applicable prior to the adoption of the Kampala definition, Antonio Cassese notes: "if the purpose of the relevant international rules is to protect the world community from serious breaches of the peace, one fails to see why individuals operating for non-state entities should be immune from criminal liability for aggressive conduct." ${ }^{36} \mathrm{He}$ classifies terrorist armed groups, organized insurgents, liberation movements and the like as "non-state entities."

In the post 9/11 world, when aggression by non-state actors is an equal, if not more of a threat, it would greatly enhance the effectiveness of the ICC if the crime of aggression would be inclusive of non-state actors as well.

Acts of internal aggression bypassed by the definition clause. Under the current setup, the international nature of the crime of aggression is a pre-requisite of Article 8 bis, i.e. a state must use its armed force against the sovereignty, territorial integrity or political independence of another state in order to attract individual criminal responsibility for the crime of aggression. Thus, internal aggression, in very definite terms, stands excluded from the scope of Article 8 bis. This exclusionary definition

\footnotetext{
Scheffer, "The Missing Pieces," 84.

Scheffer, "The Missing Pieces," 84.

Antonio Cassese, International Criminal Law, $2^{\text {nd }}$ ed. (Oxford, 2008), 157.
} 
may tend to prejudice the functionality of the ICC inasmuch as internal aggression is a "favorite tactic of ISIS and other non-state actors determined (sometimes successfully) to seize territory within a state." ${ }^{37}$

On the other hand, the rest of the international crimes under the Rome Statute, namely, genocide, crimes against humanity, and war-crimes, make individuals liable for internal violations as well. For instance, Sudanese President Omar Al Bashir's case is at the pre-trial stage for five counts of crimes against humanity, two counts of war-crimes and three counts of genocide allegedly committed in the Darfur region falling within the territory of Sudan. ${ }^{38}$ It may be advantageous to widen the ambit of the crime of aggression to cases of internal violations as well, in line with the rest of the international crimes.

\section{Conclusion}

When years passed after the conclusion of the Nuremberg and Tokyo Trials without any significant developments relating to the crime of aggression, it seemed as though the growth of the crime of aggression had reached a grinding halt. Post Nuremberg and Tokyo trials, in the past many decades preceding the adoption of the Rome Statute, several ad hoc international and hybrid tribunals came to be established to decide matters pertaining to core international crimes, such as genocide, crimes against humanity, and war crimes, but nothing was effectively undertaken in the international domain to bring the perpetrators of the crime of aggression to justice.

With the recent activation of the crime of aggression under the Rome Statute, there is much to celebrate for the international community. This is indeed a defining moment for the field of international criminal law. However, a closer look at Article 8 bis of the Rome Statute reveals the many inadequacies within the definition clause.

To reiterate, cyberwarfare and the rapid rise of terrorism from non-state actors is posing a serious threat to international peace and security in this day and age. Cyberwarfare has blurred the physical boundaries, making aggression possible even without the use of armed forces or the physical transgression of another nation-state's boundaries for that matter. Similarly, aggression from non-state actors is also on the rise. There is a need to dissolve the lines between acts of aggression committed by

\footnotetext{
Scheffer, "The Missing Pieces," 84.

38 International Criminal Court. The Prosecutor vs. Omar Hassan Ahmad Al Bashir, ICC-02/05-01/09. Available from: https://www.icc-cpi.int/darfur/albashir
} 
state-actors, on the one hand, and by non-state actors, on the other. As long as an act of aggression is committed, it must not go unpunished, irrespective of the source.

There is a pressing need to expand the relatively narrow parameters of Article 8 bis of the Rome Statute so as to make it possible for the ICC to deal with exigencies emerging in the $21^{\text {st }}$ century. In its current structure, Article 8 bis is ineffectual in delivering justice against the expanding vistas of new-age crimes of aggression.

There is a real danger of jeopardizing the ICC's mandate if a series of amendments are not passed towards the true empowerment of the ICC in regard to the crime of aggression. The author is of the informed opinion that the threats emerging from (a) non-traditional means of warfare, such as cyberwarfare, (b) non-state entities, such as terrorist groups; and (c) internal acts of aggression must necessarily be brought within the ambit of Article 8 bis in order for the ICC to be able to effectively deal with the dangers of the $21^{\text {st }}$ century.

In light of the recent activation of the crime of aggression, it is fair to state that although we have come a long way, a far more treacherous path lies ahead. Once the court undertakes its first prosecutions for the crime of aggression, there will be more clarity on the issues surrounding the definition clause. In the meantime, the international community must tread with caution.

\section{References}

Ambos, Kai. "The crime of aggression after Kampala." German Yearbook of International Law 53 (2010).

Bachmann, Sascha-Dominik and Gerhard Kemp. "Aggression as 'Organized Hypocrisy?' - How the War on Terrorism and Hybrid Threats Challenge the Nuremberg Legacy." The Windsor Yearbook of Access to Justice, Vol. 30, No. 1. (2011). Available from: http:// dx.doi.org/10.2139/ssrn.1871912

Bantekas, Illias. International Criminal Law, $4^{\text {th }}$ ed. (Oxford and Portland, Oregon: Hart Publishing, 2010).

Cassese, Antonio. International Criminal Law, $2^{\text {nd }}$ ed. (Oxford, 2008).

"Control Council Law No. 10." Control Council for Germany 50-55 (1945). Available from: https://www.legal-tools.org/doc/ffda62/pdf/

Ferencz, Benjamin B. "Address to the Diplomatic Conference of Plenipotentiaries on the Establishment of an International Criminal Court." Rome (June 16, 1998). Available from: http://www.derechos.org/nizkor/aggression/doc/bferencz6.html 
Ferencz, Benjamin B. "Can Aggression Be Deterred by Law?" Pace International Law Review 11 (1999).

International Criminal Court, Assembly activates court's jurisdiction over crime of aggression.

Press release (Dec. 15, 2017). Available from: https://www.icc-cpi.int/Pages/item. aspx?name=pr1350

International Criminal Court. The Prosecutor v. Omar Hassan Ahmad Al Bashir, ICC02/05-01/09. Available from: https://www.icc-cpi.int/darfur/albashir

International Criminal Court. "Resolution ICC-ASP/8/Res.6." (2009). Available from: https:// asp.icc-cpi.int/iccdocs/asp_docs/Resolutions/ICC-ASP-8-Res.6-ENG.pdf

International Military Tribunal. Trial of the Major War Criminals before the International Military Tribunal, Vol. 1. (Nuremberg: International Military Tribunal, 1947). Available from: https://www.loc.gov/rr/frd/Military_Law/pdf/NT_Vol-I.pdf

Kittichaisaree, Kriangsak. International Criminal Law, $1^{\text {st }}$ ed. (Oxford: Oxford University Press, 2001).

McGuinness, Damien. "How a cyber attack transformed Estonia." BBC News (Apr. 27, 2017). Available from: https://www.bbc.com/news/39655415

Rome Statute of the International Criminal Court (July 17, 1998). United Nations Treaty Collection. Available from: https://treaties.un.org/pages/ViewDetails. aspx?src=TREATY\&mtdsg_no=XVIII-10\&chapter=18\&lang=en

Scheffer, David. "The Missing Pieces in Article 8 bis (Aggression) of the Rome Statute." Harvard International Law Journal 58 (2017). Available from: http://www.harvardilj. org/2017/04/the-missing-pieces-in-article-8-bis-aggression-of-the-rome-statute/

Statute of the International Military Tribunal (8 Aug. 1945, 82 UNTS 1951).

The United States of America vs. Wilhelm von Leeb et al. (Nuremberg: US Military Tribunal, 1948).

United Nations. "Draft resolution of the Assembly of States Parties on the continuity of work in respect of the crime of aggression." (2002). Available from: https://documents-dds-ny. un.org/doc/UNDOC/LTD/N02/472/04/PDF/N0247204.pdf?OpenElement

United Nations. Preparatory Commission for the International Criminal Court (1999-2002). Available from: http://legal.un.org/icc/prepcomm/prepfra.htm

United Nations. "Resolution RC/Res.6." (2010). Available from: https://treaties.un.org/doc/ source/docs/RC-Res.6-ENG.pdf

United Nations General Assembly. "Resolution adopted by the General Assembly 3314 (XXIX). Definition of Aggression." (Dec. 14, 1974). Available from: http://www. un-documents.net/a29r3314.htm

Werle, Gerhard and Florian Jessberger, Principles of International Criminal Law, $3^{\text {rd }}$ ed. (Oxford: Oxford University Press, 2014). 